\title{
One Story, Many Perspectives: Reading and Writing Graphic Novels in the Elementary Social Studies Classroom
}

\author{
Erica Christie
}

\begin{abstract}
Though elementary students often read picture books in school, the growth of critical literacy has inspired teachers to select texts that engage students with literacy and social studies in more meaningful ways. Although many of these texts are traditional picture books, alternative formats like the graphic novel are also being used to invite student questioning and share multiple perspectives. This study examines the ways elementary students understand and retell a complex social studies story using multiple textual formats. Third-grade students were exposed to a picture book and graphic novel version of the true story of Alia Muhammad Baker, a courageous Iraqi librarian. After reflecting on the texts, students renarrated the story; many chose to write graphic novels. Students expressed high levels of interest in graphic novels, exhibited new perspectives on the Iraq War and active citizenship, and utilized key features of graphic novels to tell complex and multilayered social stories.
\end{abstract}

\section{Introduction}

Elementary teachers have long known the power of children's literature to bring social studies topics to life for their students. Indeed, since 1972, the National Council for the Social Studies has published an annual bibliography of social studiesthemed books, entitled Notable Social Studies Trade Books for Young People, providing K-8 educators with a comprehensive source for texts that can enhance and deepen their teaching of the subject. Such picture books provide young students with rich accounts of historical events, multiple perspectives on social studies topics, and captivating illustrations, characteristics uncommon in traditional social studies textbooks.

In recent years, a new kind of picture book has emerged in the form of the graphic novel. Graphic novels, an outgrowth of comic books, "are a hybrid comprising both visual and print texts" (Cromer \& Clark, 2007, p. 57). Graphic novels often tell lengthy and detailed stories about significant historical or sociocultural issues. In a sense, graphic novels resemble the more familiar format of picture books, as they contain the same basic elements of images and text. However, in picture books, these elements typically exist as mere accompaniments to each other. Consider the way elementary teachers often read picture books aloud, reading the text first and then turning the book towards the students to display the 
illustrations; this style of reading illustrates the disconnect between text and words sometimes found in picture books, for students can make initial meaning of the text without viewing the images, though the illustrations certainly enhance and deepen this understanding. In graphic novels, however, "the words are interpreted through the images and the images through the words" (Cromer \& Clark, 2007, p. 579). Indeed, words and images are so intertwined in graphic novels that the story itself cannot be understood without making sense of both elements simultaneously.

Despite the unique features of graphic novels, they remain an uncommon feature in the elementary curriculum, even as high-quality graphic novels are becoming more abundant in elementary school libraries (Gorman, 2008). Some educators worry that these texts are inappropriate or too explicit for young children, while others fear that the format "pander[s] to kids' wants without meeting their educational needs" (Lyga, 2006, p. 56). Mostly, though, elementary teachers seem to lack information about the genre of graphic novels and their potential within the curriculum, particularly as they relate to helping students understand social studies topics. Indeed, the little research available on graphic novels pertains mostly to secondary and post-secondary settings, leaving elementary educators to wonder if and how graphic novels can be effectively used with young students.

This paper explores the potential for utilizing graphic novels to help young students make sense of complicated social studies topics, understand multiple perspectives on social issues, and develop a critical stance. First, the unique features of graphic novels are explicated and the theoretical lens of critical stance is explored. Next, I examine the ways that students in one third-grade classroom engage with, understand, and retell a complex social studies narrative about active citizenship amid the Iraq War presented to them through both picture book and graphic novel formats. Finally, I consider the implications of this case study for elementary social studies educators, providing valuable insights as to how young students understand graphic novels, the power of retelling the story using alternative formats, and the potential for students to develop a critical stance as they engage with these new literacies.

\section{Making Sense of Graphic Novels}

Reading a graphic novel is a decidedly different experience than reading a picture book or traditional novel. Cromer and Clark (2007) assert that successful student interactions with this format require recognition and development of four unique features or skills: time, intertextuality, visual literacy, and hypertextuality (p. 578). First, reading graphic novels is often more time consuming than reading picture books, as readers need extra time to examine each frame, decipher text and images in relation to each other, and identify multiple pathways through the story. Second, graphic novels rely on a dynamic interplay between text and images. Known as intertextuality, words and images are intimately linked in graphic novels, making it impossible to make sense of either without the other. Readers of graphic novels must learn to interpret words through the images and images through the words in 
order to completely understand the story, a skill that is not typically required when reading other literary formats (Cromer \& Clark, 2007). Hammerberg (2001) describes this relationship as synergistic: “'Text' becomes a conglomeration of both. Words appear in pictures and over pictures in ways that require a nonliteral reading of the printed text, for to only read the words for their literal meaning would be to escape with no meaning whatsoever" (p. 209).

Third, graphic novels require readers to hone their visual literacy skills, analyzing images in highly nuanced and complex ways. Because images are such an essential component of graphic novels, readers must learn to read images as they do text, analyzing facial expressions, extrapolating mood and tone, and decoding scenes to search for meaning and fully understand the plot. Moreover, graphic novels often vary the size of the frames or panels of the story, challenging the visual literacy skills of readers. For example, authors might add spaces between panels, use a wide variety of panel sizes and shapes, or overlap frames, creating different visual effects for readers to interpret as they read (Cromer \& Clark, 2007). Understanding these visual changes is crucial to understanding the sequence and relative importance of events within the story. One large panel on a page, for instance, likely depicts a moment of great importance within the plot, whereas a page with many frames might indicate a fast-paced action scene or dialogue between characters. Fourth, graphic novels require readers to consider new ways of reading text, moving beyond the linear, left to right, format typical of many genres. This skill, known as hypertextuality, enables readers to take multiple pathways through the text, at various times reading the text vertically, horizontally, in a circular pattern, or from the bottom-up. Often, graphic novels offer multiple ways to read the text, empowering the reader with the freedom and decision-making capability to decide how to move through the story in the most meaningful way (Cromer \& Clark, 2007).

In addition to these four skills, graphic novels also require readers to toggle between multiple perspectives. As dialogue is typically written in first-person speech bubbles, each character within a graphic novel can use the "I" voice, as opposed to picture books which typically tell stories through one perspective or voice (Hammersberg, 2001). Indeed, this idea of multiplicity is important for students seeking to make sense of graphic novels, as these texts ask readers to juggle "multiple sources of information to draw on, many possible interpretations, and many choices for interacting within the text" (Hassett \& Schieble, 2007, p. 67). Even the reader's own perspective is valued in graphic novels, as evidenced by the author providing many paths through the text, ultimately leaving the power to make meaning of the story in the hands of the reader.

Beyond integrating these literacy elements, what makes graphic novels compelling for the social studies educator? For one, many graphic novels address complex social and historical themes. Frey and Noys (2002) assert "the form has actually been the site for some sustained and sophisticated engagements with the problems of representing historical events" (p. 255). Indeed, authors of graphic novels have not veered away from controversial social issues in their texts. Some of the most well-read and often-discussed graphic novels include Maus: A Survivor's 
Tale (Spiegelman, 1986) about the Holocaust, The Complete Persepolis (Satrapi, 2007) about a young girl in the Irani Revolution, Deogratias: A tale of Rwanda (Stassen, 2006) about the Rwandan genocide, The 9/11 Report: A Graphic Adaptation (Jacobson and Colon, 2006) about the events of September 11, 2001, Pride of Baghdad (Vaughan, 2008) about the American bombing of a zoo in Iraq, and People's History of the American Empire (Zinn, Konopacki, \& Buhle, 2008).

These texts differ from typical social studies textbooks or other historical texts in that 'the graphic novel is a site where 'history' itself, or representations of history, are put into play: interrogated, challenged, and even undermined" (Frey and Noys, 2002, p. 258). Rather than simply providing the reader with historical information or "telling" history, Frey and Noys (2002) argue that the graphic novel format offers "a testing place to probe the limits of history and historiography, whether that be 'traditional', 'modernist' or 'postmodernist'” (p. 259). This idea of "testing" or "playing" with history is unique to the graphic novel format and might be particularly compelling to young readers who feel disconnected by the typical way of representing history as impersonal and fixed. When history is open to interpretation, as it is in graphic novels, readers can be a part of the history-making process, asking questions, analyzing information, and making decisions. Students become active and informed historians, rather than simply passive recipients of history.

Further, graphic novels have the unique capacity to tell multi-layered social studies stories that encourage the reader to consider new and multiple perspectives. These perspectives are typically delivered to readers through the eyes of highlypersonalized characters, depicted in both illustrations and text. Whether fictionalized or not, such characters offer compelling and dynamic entrances points for readers to begin to interpret history for themselves, a far cry from the typically distant and dry representation of history found in social studies text books (Baron \& Levstik, 2004). Barton and Levstik (2004) assert that recognizing the perspectives of others, particularly those in history, is an important component of developing historical empathy and learning to care about people, places, and events in history and today.

\section{Theoretical Lens}

This study utilizes the theoretical lens of critical stance as proposed by Lewison, Leland, and Harste (2008). Building upon ideas of critical literacy (Lewison, Flint, \& Van Sluys, 2002; Luke \& Freebody, 1997; Janks, 2000) and participatory social action (Oakes \& Rogers, 2006), critical stance is a way of thinking and being that is essential to the democratic process. Critical stance is defined by four interrelated dimensions: conscious engagement, trying on alternative states of being, responsibility to inquire, and engaging in reflexivity. The first dimension, conscious engagement, refers to an "ongoing cycle of reflection, deliberation, inquiry, and action" in one's own thoughts, but also in the classroom and community (Heffernan \& Lewison, 2009, p. 19). The second dimension of critical stance entails trying on new and alternative ways of being. This requires a degree of risk-taking and playing 
with new discourses and identities. When students try on alternative ways of being, they have to examine their own positionality within situations and understand the multilayered, multimediated nature of power, history, and literacies (Heffernan \& Lewison, 2009). The third dimension, responsibility to inquiry, encourages an attitude of questioning, problem-posing, and investigation. Students are encouraged to inquire about the nature of knowledge and power, as well as consider history and social issues from "multiple and contradictory viewpoints" (Heffernan \& Lewison, 2009 , p. 20). The final component of the critical stance framework is reflexivity, in which students think critically about their own complicity in maintaining the status quo and reflect on alternative ways of teaching, learning, and being.

The critical stance lens is helpful to this study for several reasons. First, it provides an important link between the fields of literacy and social studies. Engaging students in reading and writing graphic novels on social issues is inherently a cross-curricular, integrated activity. Second, young people with a strong critical stance are capable of critiquing, questioning, and engaging in the civic process, a major goal of social studies education. Therefore, helping youth develop and take a critical stance when engaging with texts such as graphic novels is an important aspect of social studies education.

\section{Methods of Inquiry}

\section{The Texts}

The impetus for this study arose from my discovery of two excellent, though very different, children's books written about the same topic, the true story of Alia Muhammad Baker, the chief librarian of the Central Library in Basra, Iraq. In 2003, in the face of oncoming war, Baker became concerned that her library, and the irreplaceable stories and histories held within it, would be destroyed. After unsuccessfully appealing to the Iraqi government for a safe place to protect the books, Baker decided to save the books herself, sneaking volumes home with her every night. As the war inched closer to Basra, Baker asked her neighbors for help in saving the books and together they risked their lives to smuggle over 30,000 books to safety. Nine days later, the library was burned to the ground and the rest of the collection was lost. Under her guidance, a new library was constructed in 2004 and Basra was reinstated as chief librarian.

The story of Baker's courage and commitment to saving the books of Iraq is told in two different children's books. The Librarian of Basra: A True Story from Iraq by Jeannette Winter is a picture book geared toward younger readers. The book features brightly-colored, simplistic illustrations with one or two sentences of accompanying text on each page. The text offers few details about the historical context of the war in Iraq, focusing instead on Baker's courage in saving the books of her nation and her hopes for peace. Alia's Mission: Saving the Books of Iraq by Mark Alan Stamaty tells Baker's story through the graphic novel genre. Each page consists of a series of frames containing hand-drawn, black and white images and short amounts of text, often written in dialogue bubbles. The first page of this text features a flying, talking book introducing Baker as a "real-life superhero;" this caricatured 
book goes on to narrate the rest of the story, appearing again to conclude the book in its final pages. Unlike Winter's picture book, Stamaty's text contextualizes Baker's story within the war and offers a distinct perspective on Saddam Hussein. For example, the talking book sets up the story by stating, "the year is 2003. Iraq is a trouble nation ruled by a cruel dictator, Saddam Hussein, who is hated and feared by most of his people." The book is geared toward a slightly older reader than Winter's picture book, appealing perhaps to the upper elementary/middle school audience.

Though different in their approaches and content, both books tell Baker's fascinating story in a compelling and engaging way, offering young readers a unique perspective on the war in Iraq. After reading each text myself, I was curious how students would react and make meaning of the two different versions of the story. Would students prefer one format over the other? What would students take away from each text to help them understand this complicated social studies story? Moreover, how does engagement with these two texts help students understand the Iraq War specifically and the concept of war more generally? My desire to explore these questions led to the creation of this case study, which I conducted with a class of third grade students.

\section{The Study}

The study began with a discussion about what students already knew about the war in Iraq. Next, students were introduced to Baker's story and the two texts. Students then listened as I read aloud The Librarian of Basra, the picture book by Winter. I read each page as I showed students the illustrations, scanning the book across the room to ensure that all students could see the images. Next, I read aloud Alia's Mission, the graphic novel by Stamaty. To ensure that students could see the detail within each frame and read the text and images simultaneously, I chose to project this book on a large screen, zooming in and out with a projector to capture the detail of each image/text frame. After listening to both texts, I engaged students in a class discussion about the two versions of the story. Students were asked to share their thoughts on the two formats, as well as reflect on what they learned about Baker as a historical figure and role model for civic action, about the Iraq War, and about war in general through these two books. Finally, students were given the opportunity to retell Baker's story in their own words. Given plain white paper and open-ended instructions, students were free to retell the story however they saw fit, drawing from the formats of the two books or creating a new format for sharing the story. After students finished their retellings, the class reconvened to share their stories and explain why they chose to tell their story as they did. Students reflected on how retelling the story in their own words offered a unique perspective on the two books and helped them better understand Baker's actions and the Iraq War. 


\section{Participants and Setting}

This study was conducted in one third grade classroom at a public school located within a large school district on the urban fringe of a major Midwestern city. Seventy-nine percent of students at this school were identified as white, $7 \%$ as Hispanic, $7 \%$ as multiracial, $5 \%$ as Black, and $2 \%$ as Asian. More than a third of the students (38\%) qualified for free or reduced lunch. The school consistently scored well on state standardized tests, with $85 \%$ of students passing in 2008-2009, nearly $15 \%$ higher than the state average. The participating classroom was composed of 22 students, 14 females and 8 males, and was taught by an African American male teacher. For three months prior to this study, I worked closely with these students and the teacher on an extensive research project on a related topic. As such, I was quite familiar with the class and was treated as a respected teacher and researcher at the time of this study.

\section{Data Sources and Analysis}

This qualitative case study utilized a range of data sources. First, I took extensive field notes during my time teaching and observing in this classroom. These field notes were supplemented and strengthened by audio recordings made of during the lessons. Recordings were transcribed and combined with my field notes to create a "thick record" of the classroom experience during this case study (Carspecken, 1996, p. 49). This thick record was further supplemented by photographs taken throughout the study depicting various elements of the lessons and student work. Additionally, I collected and photocopied the students' written retellings. Finally, I conducted short, informal interviews with approximately ten students, asking them to orally share their retelling and explain their thinking and decision-making process with me. By using a wide range of methods, I aimed to more fully capture the experience of participants and in turn increase the fruitfulness of my findings.

The thick records and interview transcripts were coded in order to identify emerging themes. I utilized a Grounded Theory Approach to coding, as developed by Glaser and Strauss (1967) and Strauss and Corbin (1990), to identify codes that are internal or grounded in the data, emerging from the participants' experiences. Grounded theory allows the researcher to identify implicit ideas that participants hold about their lives and bring these often unspoken theories of meaning to the surface. I analyzed the written documents and photographs in a similar manner, asking questions about meaning and representation. The answers to these questions helped me identify codes and eventually categories and themes which supported and complicated the themes that emerged from the other sources.

\section{Findings}

In this section, I share findings related to three main themes. First, students expressed great interest and enthusiasm for the graphic novel genre, particularly in comparison to the picture book, despite their lack of previous knowledge and experience with the format. Second, engaging with this graphic novel helped the students understand the reality of the war, the actions of a unique active citizen, and 
an Iraqi perspective. Finally, students exhibited an implicit understanding of the key features of graphic novels in their retellings of the story of Alia Baker. In particular, students showcased intertextuality, visual literacy, and the ability to tell stories from multiple perspectives, including their own, in their retellings. Each of these themes will be explored in detail in the following sections.

\section{“Cool! It's a graphic novel!"}

Students were instantly drawn in by Stamaty's graphic novel, Alia's Mission. As soon as I announced we would be reading a graphic novel, I heard several students proclaim "yes!" and "cool!" Despite this enthusiasm, only a few students, all boys, indicated that they had ever read a graphic novel before and nobody could recall reading one as part of a school assignment or curriculum. I projected the book onto a large screen and immediately upon opening the first page of the text, students started laughing and cheering in response to the talking, walking book character that Stamaty uses to narrate the story and introduce readers to Baker, who he proclaims as a real-life superhero. This element of fantasy was quite captivating to students, who had no trouble switching between this fictional character and the true story presented in the book. During my reading of the book, students asked me to stop several times to zoom in on certain panels, read speech bubbles, ask questions, and provide extra time for them to closely examine the images. When the author dramatically fills the page with the scene of the library burning down, students audibly gasped in horror, clearly understanding the gravity of the situation.

Students also listened intently as I read the picture book, The Librarian of Basra, however they did not show the same enthusiasm or interest in the story as they did while reading the graphic novel. Even though this version was more colorful and shorter, students seemed less captivated by the story. They asked no clarifying questions nor did they make any connections with the text; it was as though they were reading a book that was completely separate from their own lives. Perhaps this is because they are quite familiar with picture books, whereas the graphic novel was decidedly different, and thus more exciting, than books they typically read in school.

In discussions afterward about the two books, students overwhelmingly noted that they preferred the graphic novel over the picture book. Several students mentioned that the pictures and text in the graphic novel were more specific and detailed, providing helpful information that complicated the story. Interestingly, I was initially concerned that Stamaty's graphic novel would be too detailed for third grade students, as he contextualizes Baker's story within the war in complex ways that Winter's more simplistic picture book does not. However, this level of detail seems to be exactly what drew students into the story; they appreciated knowing specific facts and information, particularly when this detail was presented in an engaging manner. Sean ${ }^{4}$ explained, "I don't really like picture books because they don't tell a lot of words, but graphic novels have a lot of pictures and words." Wyatt

\footnotetext{
${ }^{4}$ All of the names in this paper are pseudonyms.
} 
further indicated that he learned more by reading the graphic novel because "instead of just having one picture you can put a whole bunch more details and stuff."

\section{"Who would want to blow up a library?"}

Prior to reading either of these stories, I asked students to share with me what they already knew about Iraq and the war taking place there. Comments ranged from vague ideas about what is happening there- "they are having something related to a war there"-to more specific statements, such as "there is lots of soldiers fighting in Iraq." Mitch indicated that Iraq made him think of his mom's boyfriend, who is currently serving in the military there. Destiny said that when she hears the word Iraq, she thinks of the word "destroy," explaining that "like Iraq, like it messed up everything." Another student explained that soldiers are fighting because "they are trying to protect us, like the Iraqians and us, because we took their land and they want it back." Overall, students seemed unsure what to think about Iraq and were hesitant to even venture a guess, perhaps a sign that very little teaching or discussion about the war in Iraq is happening in their classroom or at home. The little background knowledge they did possess revolved around American soldiers going to fight in Iraq and an overall impression that the United States was fighting against the Iraqis.

After reading the two books, students expressed surprise over several facets of the war. Wyatt indicated that "I didn't know that they blew up a library." He goes on to share that he thought wars happened out in the desert and away from ordinary people, not so close to places that normal people use, like libraries. Nora further questioned, with great exasperation, "who would want to blow up a library?" Likewise, others were surprised that people's houses were destroyed during war. Emily noted "whenever we have wars, we destroy people's homes and some of their most precious things," a salient insight into the Iraq War, but also the consequences of war more broadly. Further, Mitch was amazed at how commonplace it seemed for buildings to be blown up in Iraq and the government's apparent disinterest in helping stop the destruction. He said, "I learned that people in Iraq don't really care that they are getting bombed. They are used to the buildings being bombed. The government didn't want to help save the library." Students also expressed dismay that looting occurred after buildings were destroyed, as Stamaty described people running into the remains of the library to steal rugs and pencil sharpeners.

After reading the two books, students revealed an understanding of a completely new side of the war, an Iraqi perspective. Previously, their limited knowledge about the war seemed to center on the American position, particularly the point-of-view of American soldiers fighting in the war. The story of Alia Muhammad Baker, in contrast, offers a fresh perspective on the war, offering a glimpse into ordinary life in Iraq through the eyes of an unlikely hero, a courageous and civically-minded elderly Iraqi woman. One student was impressed that "she is very old and she saves all these books at that age," while another proclaimed her a real-life hero who "saved the history of her country." Thinking about the war 
through the eyes of Baker was both surprising and compelling for students, who knew little about life in Iraq and previously thought the only heroes in the war were the American soldiers. As such, engaging with the graphic novel helped students visualize the realities of war and understand multiple perspectives on it, particularly the experiences of the Iraqi people.

\section{In Their Own Words}

After reading and discussing the two texts, students were asked to retell the story in their own words and pictures. With minimal, open-ended instructions and blank, white paper as a canvas, students had the freedom to choose any format they wanted to retell the tale of Alia Baker. Of the twenty-two participating students, twelve chose to retell the story in a graphic novel format, two created more traditional picture books, seven wrote text-only stories, and one student used images and stand-alone words to tell the story.

In this section I will share some of the most interesting features of the student retellings. In particular, I will look closely at the retellings of students who utilized the graphic novel format. Although students had limited prior exposure to this format, many students exhibited an implicit understanding of the key features of graphic novels, including intertextuality, visual literacy, and the ability to tell stories from multiple perspectives, including their own. I will also examine the retellings of students who utilized formats other than the graphic novel and share some of the students' explanations for how they made decisions regarding which format best fit their retelling.

Intertextuality. First, these students played with the idea of intertextuality, the co-dependency of text and images in graphic novels. Sean (Figure 1) created a graphic novel that requires readers to closely examine the images and text simultaneously. He only writes text in the form of speech bubbles, providing no background information or text outside of the framed image. Several of his panels have no words at all; instead he uses images to show action and move the storyline forward. Similarly, Amanda (Figure 2) uses images to complete thoughts she begins in words. For example, she writes, "And it starts like this..." on the top of a framed image of Baker driving to work, allowing the image to serve as the remainder of her sentence. It would be impossible for the reader to understand Amanda's story by examining the pictures or words on their own, but together they read as a singular text. 


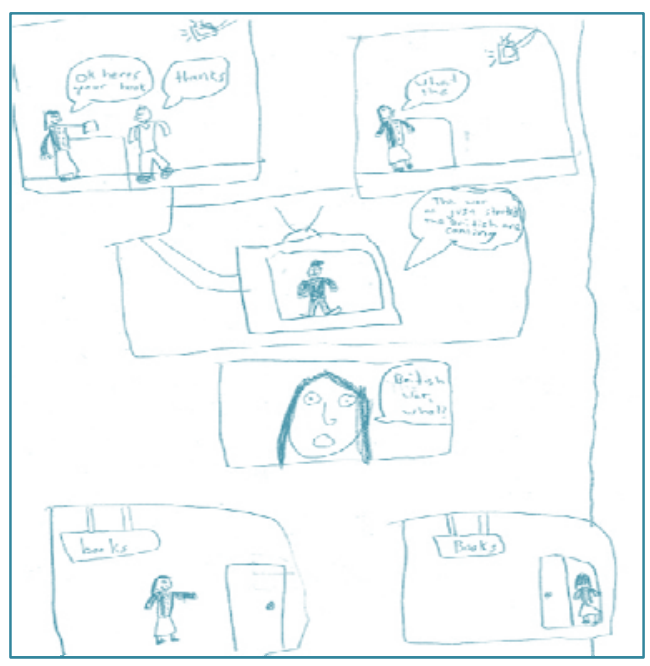

Figure 1

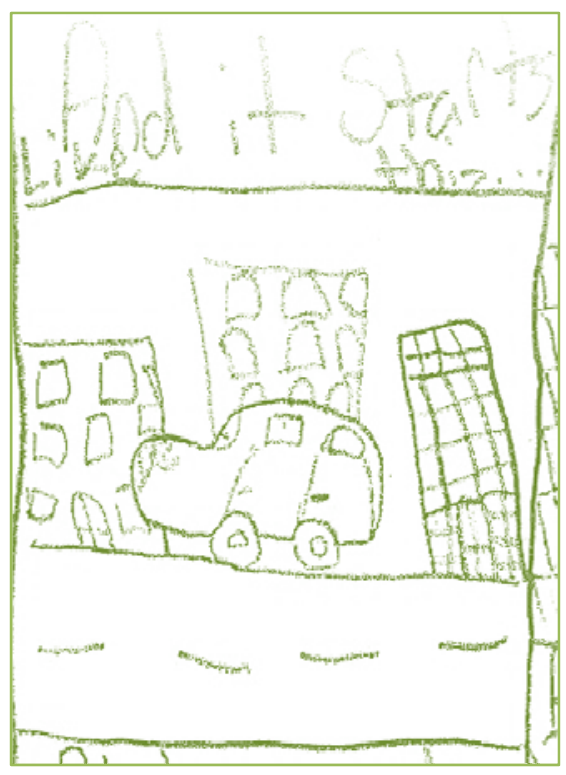

Figure 2

Visual Literacy. Students also played with the idea of visual literacy. Jasper (Figure 3) varied the size of his panels depending on the importance and type of information contained within them. For example, one page of his book contains 4 frames detailing the transfer of the books from the library to the restaurant. The four frames are crowded together and give the reader a sense of action, as if the efforts to save the books are happening quickly and at a frantic pace. Later, Jasper uses one large panel (Figure 4), the same size as the four described above, to depict the burning of the library, adding drama and a pause to the most climactic moment in the book. By varying the frames in this way, Jasper controls the pace of the plot for the reader and shows an understanding of the relative importance of various moments in the story. Other students also displayed an understanding of visual literacy skills when they used images to display emotions and tell important parts of the story without using words. For example, in one panel of her story Amelia (Figure 5) writes "Alia and her friends took the books so they won't get on fire." The accompanying image in this panel shows two women carrying stacks of books. One women has a large tear running down her face while the other has a dialogue bubble drawn from her mouth, showing that she is yelling "Hurry up!." In decoding Amelia's image, the reader understands that moving the books out of the library was a sad and scary experience for Baker and her friends, who felt pressured to move the books as quickly as possible. Yet this urgency and emotion does not come through in Amelia's rather vague sentence. It is only through reading the image in relation to the words that the full meaning of Amelia's text is revealed. 


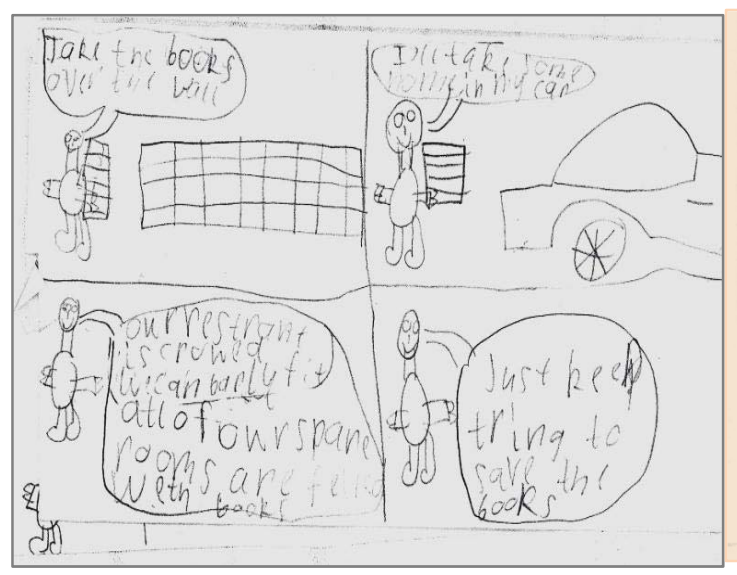

Figure 3

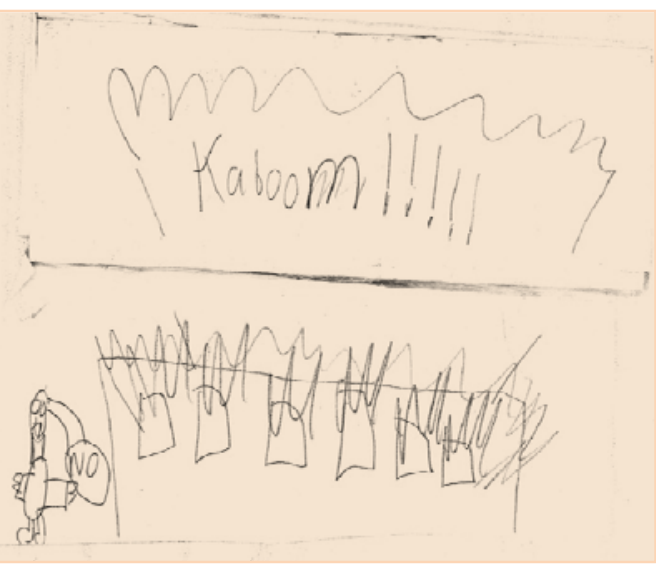

Figure 4

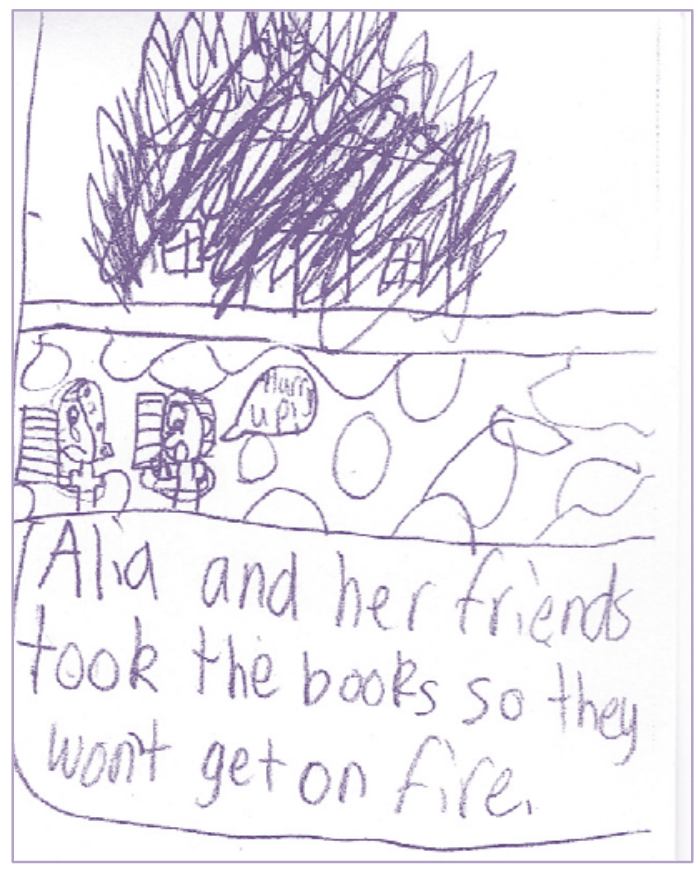

Figure 5

Multiple Perspectives. Students who chose to retell the story through the graphic novel format also displayed an understanding that graphic novels provide unique opportunities to share multiple perspectives. Nine of the twelve students wrote at least some of their text in speech bubbles, forcing the reader to switch between multiple speakers and perspectives. Unlike picture books, where the speaker is often identified with the "he/she said" phrase and the speech act is placed in quotation marks, these students used speech bubbles to show who was speaking and provide multiple points-of-view on the story. For example, Amanda (Figure 6) drew a panel in her book depicting two people in conversation. At the top of the panel, she writes "And people start saying rumors that might come true." Beneath this text, one character exclaims, through a speech bubble, "Oh no people might die" 
and the other responds "Will my family survive?" Through using the speech bubbles in this way, Amanda provides readers with a glimpse into the thoughts and feelings of people in Basra at the time of the war, generating a more complete understanding than if she had simply told the story from one perspective. Beyond speech bubbles, several students actually created a new character to narrate or introduce their story, adding a fictional element to this true story. Indeed four students followed the lead of Stamaty, the author of Alia's Mission, in introducing a talking, walking book to help tell the story. Madison (Figure 7) begins her retelling with an image of a smiling book stating "The year was 2003" while Allyiay's cover depicts a book with a peace sign on front declaring "Read this book!."

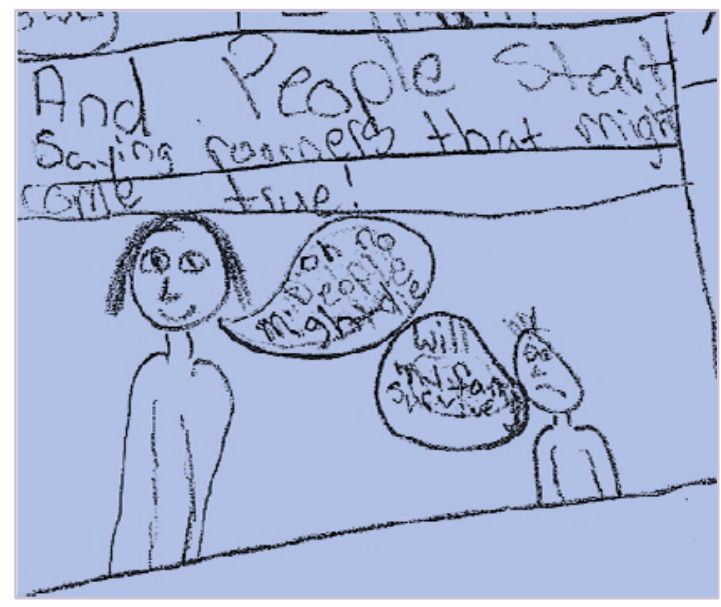

Figure 6

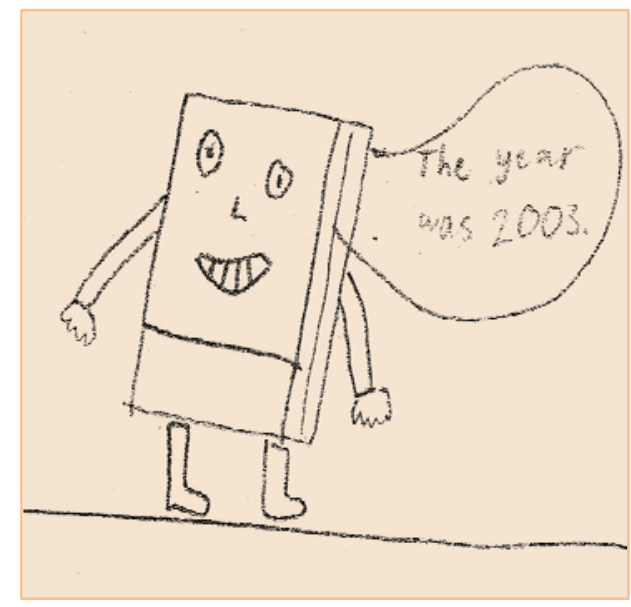

Figure 7

New Perspectives. Perhaps most interestingly, many students included a new perspective in the text, their own. Students embellished stories, changed facts, and reworked the ending of the story, adding their own unique perspective to Baker's story just as the authors of the two books did. Many students displayed an urge to conclude their books on a positive note, even if this positivity was not accurate to the factual details of the story. For example, Maya finishes her story by writing " 6 months later there was a new library. Even more kids came than before." Indeed, there was not a new library six months later, nor were students provided any information about attendance at the new library. Similarly, Rebecca writes "she lived happily ever after in her new library!" at the conclusion of her retelling, a statement that vastly oversimplifies the hardship Baker endured, including suffering a stroke on the day of the fire, in order to save and eventually rebuild the library. Like Maya and Rebecca, Henry seems determined to put a positive spin on the story, titling his book "Alia's Worst to Best Day Ever!" In his retelling, the fire department comes to the rescue of the library and Alia is happy because the library "was harmed a little," leaving "the books still good to read!" This retelling glosses over all of the angst and fear Baker feels about losing the books in the library and oversimplifies the story to such a point where it is simply inaccurate, for the library was burned to 
the ground and many of the books went with it. It is hard to imagine Baker proclaiming the burning of the library to be her "best day ever," as Henry declares.

Other formats. Of course, not all of the students utilized the graphic novel format to retell Baker's story. Seven students chose to use mainly text to retell their story. Several of these students wrote lengthy pages of text, adding a great amount of detail from the original books into their retellings, while others wrote only a few sentences, simplifying the story significantly. Without using images, Charlie turned to other visual techniques, such as using all capital letters and exclamation points, to signify important moments in the story, as in "she saw a sign that said war TOMORROW!!" Likewise, Claire dramatized the climactic moment of the book when she wrote, "soon the war came closer and closer and KABO0M! The library was on fire!" Three of the students who wrote text-based books began their stories with the phrase "one day..." and concluded their retellings by writing "The End," drawing from traditional story-telling techniques as though Baker's story was fictional.

Student Rationale. After completing their retellings, students were asked to explain why and how they choose to retell the story. One student exclaimed that he chose to use pictures and text to share his story because, "I think that pictures alone wouldn't give a good description of what happened because...if you just showed pictures of a war, they might think the story was about a war, not about saving a library." Emily elected to use a graphic novel format because, "I think I can tell the story better using the images and the short words." Similarly, Maya noted that it "would be boring to have one big picture and just a couple of words. I wouldn't be able to fit the whole story like that.... If I just used words, I wouldn't be able to tell the whole story." Jasper also settled on the graphic novel because he found it useful to tell the story through words and images, though he originally wanted to create a wordless book. "At first I wanted to just do pictures, but then I realized I couldn't really explain the story in pictures alone so I needed to use some words too," he explained. Several students who chose to use mainly text in their retellings indicated that they did not like to draw or did not feel like drawing that day.

\section{Implications for Elementary Social Studies}

Though this case study was limited in its scope, it provides valuable insights to elementary educators about the power and potential of using graphic novels to teach social studies. First, students in this class made it abundantly clear that they enjoy reading graphic novels, often more so than they do a traditional picture book. The graphic novel we read, Alia's Mission, offered immense details in the text and images, resulting in a longer, more complicated story than the picture book version. Ironically, this complexity made me initially leery to share the graphic novel with this class of third-graders, who I feared would get confused or bored by the nuanced plot. Instead, it is precisely this level of detail that engaged students with the graphic novel; several students even expressed disappointment over the fact that the picture book version glossed over so many facets of the story, such as Baker's stroke after the library burns down. More than simply enjoying the graphic novel version of the story, students also showed a remarkable ability to read the visual and textual 
components of the book as a singular text. They were entranced by the black and white images in Stamaty's book and asked repeatedly for extra time to examine the images and read the accompanying speech bubbles. Whereas they passively listened to my reading of the picture book, they wanted to linger inside the pages of the graphic novel, reveling in the intricacies of the images.

This level of student engagement suggests that elementary educators need not shy away from graphic novels for fear that they are too complex or detailed, but rather utilize them in the curriculum for exactly these reasons, providing elementary students with the in-depth information they crave through a genre that is compelling for young people. Whereas social studies text books can also provide detailed information about historical or socio-cultural events, such texts are typically quite dry to read, with long paragraphs full of facts and few illustrations. Conversely, graphic novels can present the same type of information in a more interesting way, offering multiple perspectives on events, personal insights into social studies stories, and powerful illustrations that propel the story forward. Picture books can also do this, and certainly many excellent texts do, but graphic novels have a tendency to be more detailed, lengthy, and nuanced than the typical children's picture book, offering great possibilities to tell social studies stories in complicated, yet accessible, ways.

Secondly, this case study suggests the power of having students reinterpret and retell social studies stories in their own words. Rather than simply discussing and analyzing the two texts, students were encouraged to do something with Baker's story, creating a new version-their own. This turned a typically passive classroom exercise, listening to a book read aloud, into a more active one, in which students were reconstructing the story and taking on the role of authors and illustrators. Students were given much freedom in choosing how to best retell the story of Alia Baker; they needed to make key decisions about what content to include and what to leave out, as well as what format-graphic novel, picture book, text only, or an original style-would be most appropriate for their retelling. "Figuring out what to say, what to depict, and how these modes should be interrelated in their books are all important tasks for the child," assert Pappas and Varelas (2009, p. 210), who further state that the task of creating multimodal texts can reveal underlying content knowledge that often goes unidentified when teachers emphasize one mode, usually writing, exclusively. "In a nutshell, concentrating only on written text clearly does not paint the 'whole picture'" (Pappas and Varelas, 2009, p. 210).

What was particularly interesting about the students' retellings in this case study was that so many of the students utilized the graphic novel format to share their stories. Even though the students had little exposure and had received minimal teaching about this format, they still found the graphic novel compelling enough to try out for themselves, a strong indication of student interest in this realm of writing. Imagine the possibilities for student learning if indeed this sort of communication did become an area of teacher emphasis. As Hammerberg (2001) argues, "instruction can take place on the conceptual level of textual design and 
ever-shifting perspectives (e.g. hypertext). This kind of instruction will rely on techniques that transform the abstract into a different kind of concrete: a textual form that represents the imaginative ranges and perspectives of students" (p. 214). Beyond this sort of language arts curricular reinvention, social studies instruction could also be reinterpreted to incorporate the many lessons of graphic novels. For instance, students could use the texts as starting points to grapple with multiple perspectives on social issues, as models for their own multimodal writing, and as sites to explore their own voices as authors and illustrators of social stories.

Finally, it became increasingly evident during this case study that engagement with Baker's story through reading the two texts and participating in the retelling exercise helped students develop a critical stance (Lewison, Leland, \& Harste, 2008). In this case study, students practiced conscious engagement by making decisions about how to respond to the story and being cognizant of the power of their choices as authors and illustrators. Students played with alternative states of being when they sought to understand the multimodal nature of the books they were reading and creating, as well as when they were taking risks in their own retellings, trying out new and different ways to share their voices. A responsibility to inquire was exhibited when students asked questions about both the content of the story (i.e. "who would want to blow up a library?") and about the format for their retellings. Students also exhibited this responsibility to inquire when they questioned the viewpoints of the authors of the two texts, particularly when they considered why each author chose to include or exclude certain pieces of information, and considered the perspectives of Iraqi citizens and American soldiers in the stories.

Why does the development of a critical stance matter? Lewison, Leland, and Harste (2008) assert that ascertaining a critical stance is crucial to an individual's civic growth and essential to a community's democratic development. Young people with a strong critical stance are better equipped to engage with, question, and challenge the civic process, a major goal of social studies education. Moreover, students who possess a critical stance can imagine alternative ways of being and acting that challenge systems of injustice and the status quo, instead taking risks and trying out new discourses. Of course, the development of a critical stance is an enormous goal and one that must be shared over the course of a student's education-the students in this case study surely did not develop a critical stance simply by partaking in this short project. However, projects like this one do help students nurture their critical stance, providing opportunities to practice new discourses and try skills necessary for this type of critical engagement.

\section{Conclusion}

This case study provided third-grade students the opportunity to read, write, and re-write history using the graphic novel format. Through exploring the story of Alia Baker, students shared high levels of interest in graphic novels, exhibited new knowledge and perspectives on the Iraq War and active citizenship in general, and utilized key features of graphic novels to tell complex and multilayered social stories 
from their own perspective. Engaging with graphic novels helped students better comprehend both the content of the lesson, the realities of the Iraq War and civic commitment of one Iraqi woman, and the nature of historical narratives. In their retellings, students showed an understanding that history is open to interpretation, that there are multiple, valid perspectives on every issue, and that the viewpoints of young people matter, including their own.

The success of this case study raises questions about how we as educators can utilize graphic novels, as well as other forms of alternative and out-of-school literacies, like blogs, podcasts, online games, web pages, videos, and social networking, to similarly motivate young people to engage in the civic process and develop a critical stance. Picture an elementary classroom in which students learned about social and historical issues through these types of literacies. How different such a classroom would look and feel than the typical social studies classroom, where students learn a staid version of history from a textbook and literacy means simply reading books. Imagine a class where these literacies were nurtured, rather than marginalized, brought into the mainstream of both the literacy and social studies curricula as essential elements to teach content and promote student engagement, civic development, and critical stance. It is not implausible to think that in such classrooms the voices of more students would be welcomed, the interests of diverse populations would be considered, and the disconnection between learningat-school and learning-at-home would be minimized. This case study is but a small start—surely these ideas merit further exploration.

\section{References}

Barton, K. C., \& Levstik, L. S. (2004). Teaching history for the common good. Mahwah, NJ: Lawrence Erlbaum.

Carspecken, P. F. (1996). Critical ethnography in educational research: A theoretical and practical guide. New York: Routledge.

Cromer, M., \& Clark, P. (2007). Getting graphic with the past: Graphic novels and the teaching of history. Theory and Research in Social Education, 35(4), 574-591.

Frey, H., \& Noys, B. (2002). Editorial. Rethinking History, 6(3), 255-260.

Glazer, B. G., \& Strauss, A. L. (1967). The discovery of grounded theory: Strategies for qualitative research. New York: Aldine.

Gorman, M. (2008). Graphic novels rule! The latest and greatest comics for young kids. School Library Journal, March, 42-47.

Hassett, D., \& Schieble, M. (2007). Finding space and time for the visual in K-12 literacy instruction. English Journal, 97(1), 62-68.

Hammerberg, D. (2001). Reading and writing "hypertextually": Children's literature, technology, and early writing instruction. Language Arts, 78(3), 207-216. 
Heffernan, L., \& Lewison, M. (2009). Keep your eyes on the prize: critical stance in the middle school classroom. Voices from the Middle, 17(2), 19-27.

Jacobson, S., \& Colon, E. (2006). The 9/11 report: A graphic adaptation. New York: Hill and Wang.

Janks, H. (2000). Domination, access, diversity, and design: A synthesis for critical literacy education. Educational Review, 52, 15-30.

Lewison, M., Flint, A. S., \& Van Sluys, K. (2002). Taking on critical literacy: The journey of newcomers and novices. Language Arts, 79, 382-392.

Lewison, M., Leland, C., \& Harste, J. (2008). Creating critical classrooms: K-8 reading and writing with an edge. New York: Lawrence Erlbaum.

Luke, A., \& Freebody, P. (1997). Shaping the social practices for reading. In S. Muspratt, A. Luke \& P. Freebody (Eds.), Constructing critical literacies (pp. 185-223). Cresskill, NJ: Hampton Press.

Lyga, A. (2006). Graphic novels for (really) young readers. School Library Journal, March, 56- 61.

Oakes, J., \& Rogers, J. (2006). Learning power: Organizing for education and justice. New York: Teachers College Press.

Pappas, C., \& Varelas, M. (2009). Multimodal books in science-literacy units: Language and visual images for meaning making. Language Arts, 86(3), 201211.

Satrapi, M. (2007) The complete Persepolis. New York: Pantheon.

Spiegelman, A. (1986). Maus: A survivor's tale. New York: Pantheon.

Stamaty, M. A. (2004). Alia's mission: Saving the books of Iraq. New York: Knopf.

Stassen, J. P. (2006). Deogratias: A tale of Rwanda. New York: First Second.

Strauss, A., \& Corbin, J. (1990). Basics of qualitative research: Grounded theory procedures and techniques. London: Sage.

Vaughan, B. K. (2008). The pride of Baghdad. New York: Vertigo.

Winter, J. (2005). The librarian of Basra: A true story from Iraq. Orlando: Harcourt.

Zinn, H., Konopackin, M., \& Buhle, P. (2008). A people's history of American empire: A graphic adaptation. New York: Henry Holt. 